\title{
Reconstrucción de la articulación temporomandibular: injertos autólogos
}

\author{
Reconstruction of the temporomandibular joint: autogenous grafts
}

\author{
A. García-Rozado González
}

Resumen: Las indicaciones para la reconstrucción de la articulación temporomandibular (ATM) están bien establecidas en la literatura médica y en la práctica clínica de la Cirugía Oral y Maxilofacial. Sin embargo, la técnica reconstructiva más adecuada para cada caso permanece controvertida. El desarrollo de nuevos materiales para la confección de prótesis de ATM no ha conseguido desplazar a los injertos autólogos, que conservan numerosas indicaciones reconstructivas merced a las indudables ventajas que supone el empleo de tejidos del propio paciente.

Palabras clave: Reconstrucción ATM; Injertos autólogos; Injerto costocondral; Anquilosis.

Recibido: 25-03-2004

Aceptado: 11-04-2004

\section{Introducción}

A pesar de los considerables avances tecnológicos que ha experimentado nuestra especialidad en las últimas décadas, la reconstrucción de la articulación témporomandibular (ATM) sigue suscitando numerosas controversias y persiste como un reto importante para cirujanos orales y maxilofaciales. Entre los planteamientos terapéuticos que se han propuesto para los defectos tisulares de estructuras anatómicas de esta articulación se sitúan la abstención reconstructiva, los injertos autólogos y las prótesis articulares.

En los albores del siglo XXI resulta difícil justificar un planteamiento de no reconstruir una ATM. Ello determinaría secuelas estéticas relevantes en los pacientes y un compromiso funcional evi-

Médico Adjunto.

Servicio de Cirugía Oral y Maxilofacial.

Complejo Hospitalario Juan Canalejo. La Coruña, España.

Correspondencia:

Alvaro García-Rozado González

Rúa Perseo 15

15179 Oleiros, La Coruña, España.

E-mail: agrozado@canalejo.org
Abstract: The indications for surgical reconstruction of the temporomandibular joint (TMJ) are well-established in medical literature and even in clinical practice of Oral and Maxillofacial Surgery. The optimal reconstructive method for each case, however, is still controversial. The progressive developing of new materials to obtain better TMJ prostheses has not been enough to replace autogenous tissue reconstruction. It still maintains a great number of indications in TMJ reconstruction due to the remarkable advantages that undoubtedly provides the use of tissue harvested from the same patient.

Key words: Temporomandibular joint reconstruction; Autogenous tissues; Costochondral graft; Ankylosis.

\section{Introduction}

Despite the considerable technical advances in our field over the last decades, the reconstruction of the temporomandibular joint (TMJ) is still controversial, and it continues to represent an important challenge to Oral and Maxillofacial surgeons. Among the therapeutic proposals which have been put forward for tissue defects of anatomical structures of this joint, there is reconstructive abstinence, autogenous tissue reconstruction and joint prostheses.

At the beginning of the 21st century it would be difficult to justify the non-reconstruction of a TMJ. This would have considerable aesthetic consequences for the patient; mandibular excursion would be significantly compromised, with a clear ipsilateral-lateral deviation of the mandible, and a loss of basic functions such as mastication or even swallowing.

Complete reconstruction of TMJ by means of grafts of flaps from the patient himself is still the technique of choice in most cases. The principal advantage is the biological compatibility of autogenous tissues, the use of which is traditionally associated with reconstructive techniques. Other 
dente en la excursión mandibular, con franca laterodesviación ipsilateral de la mandíbula y menoscabo de funciones las básicas como pueden ser la masticación o incluso la deglución.

La reconstrucción completa de la ATM mediante injertos o colgajos provenientes del propio paciente sigue siendo la técnica de elección en la mayoría de los casos. La compatibilidad biológica de los tejidos autólogos es la principal ventaja que clásicamente se asocia a su utilización como técnica reconstructiva. Otras ventajas que se han reseñado son su facilidad de manejo quirúrgico, adaptabilidad funcional, mínima capacidad infectiva y de desarrollo de mecanismos inmunológicos y reducción sustancial de los costes sanitarios. ${ }^{1}$ Son todas ellas características que dotan a la reconstrucción mediante tejidos autólogos de una mayor capacidad de protección del bienestar biológico y funcional del paciente. Incluso en caso de fracaso terapéutico, la posibilidad de detrimento adicional para el paciente es poco frecuente y de escasa severidad, a diferencia de lo que acontece con las prótesis aloplásticas.

\section{Controversias}

Existen múltiples indicaciones establecidas para reconstruir la ATM. Entre ellas se pueden incluir defectos congénitos, como ausencia congénita del cóndilo o hipoplasia del mismo, o bien defectos secundarios a procesos neoplásicos, anquilosis, traumatismos severos, osteoartritis, enfermedades infecciosas o inflamatorias, procesos reumatoideos avanzados, o reacción secundaria a implantes aloplásticos de ATM.2,3 En la actualidad, y especialmente en Norteamérica, un porcentaje nada despreciable de estas reconstrucciones vienen indicadas por situaciones iatrogénicas producidas por resecciones condilares "poco juiciosas", y más comúnmente debido a la destrucción progresiva del cóndilo mandibular como resultado de cirugías repetidas o utilización indiscriminada de material aloplástico.

Los objetivos de estas reconstrucciones complejas incluyen la restauración de la morfología tridimensional y la función mandibular, disminuir las limitaciones y la sintomatología del paciente, y prevenir la progresión de la enfermedad. ${ }^{4,5}$ En los inicios del siglo XXI es indispensable añadir una prudente consideración sobre costes y efectividad de los diferentes tratamientos. Con todo ello, el método ideal de reconstrucción sigue siendo controvertido en la actualidad. Prueba de ello es la gran variedad de técnicas reconstructivas descritas en la literatura, tanto con injertos autólogos como mediante materiales aloplásticos.

Otro aspecto que suscita discusión es el manejo del disco articular y de la musculatura masticatoria en la reconstrucción total de la ATM. En caso de ser preciso realizar discectomía, la inmensa mayoría de los autores prefieren el reemplazo del disco articular. Aunque el polietileno fue el primer material aloplástico empleado para la reparación del disco articular, los polímeros de silicona y politetrafluoroetileno (PTFE) han sido de largo los compuestos sintéticos más populares durante los últimos 20 años. 6,7 Sin embargo, debido a las dificultades clínicas y biológicas derivadas de la actividad osteoclástica desencadenada por estos materiales aloplásticos, , 89 la reconstrucción disal con tejidos autólogos ha ido advantages that have been highlighted are the ease with which they can be surgically manipulated, functional adaptability, minimal capacity for infection and for the development of immunology mechanisms, and the reduction in medical costs. ${ }^{1}$ The latter are characteristics that give reconstruction by means of autogenous tissue a greater role in the protection of the biological and functional well-being of the patient. The possibility of the patient experiencing additional injury in the event of therapeutic failure is unlikely and of little consequence, as opposed to what happens with alloplastic prostheses.

\section{Controversies}

There are multiple indications established for TMJ reconstruction. Among them congenital defects should be included, as well as congenital absence of the condyle or hypoplasia, or secondary defects associated with a neoplastic processes, ankylosis, severe trauma, osteoathritis, infectious illnesses, advanced rheumatoid processes, or secondary reaction to alloplastic implants in TMJ.2,3 Currently, and especially in North America, a considerable number of these reconstructions are advised as a result of iatrogenic situations following "imprudent" condyle resections and, more commonly, due to progressive destruction of the mandibular condyle as a result of repetitive surgery or indiscriminate use of alloplastic material.

The objective of these complex reconstructions includes the restoration of three-dimensional morphology and mandibular function, diminishing the limitations and symptomatology of the patient, and preventing the progression of the illness. 4,5 At the beginning of the 21st century giving prudent consideration to costs and efficiency of the different treatments is indispensable. With all this in mind, the ideal method of reconstruction continues to date being controversial. Proof of this is the great variety of reconstructive techniques described in the literature, with autogenous grafts as well as with alloplastic material.

Another aspect which gives rise to discussion is the manipulation of the articular meniscus and masticatory muscles in total reconstruction of the TMJ. In the event of a meniscectomy being necessary, a great many authors prefer the replacement of the joint disc. Even though polyethylene was the first alloplastic material used for the repair of the joint disc, silicone and polytetrafluoroethylene (PTFE) polymers have been the most popular synthetic components by a long margin over the last twenty years. 6,7 However, due to clinical and biological difficulties derived from osteoclastic activity which started with alloplastic material, 8,9 the reconstruction of the meniscus with autogenous tissue is gaining more followers. Among the tissues that have been described as substitutes of the articular meniscus, of note is fascia lata, muscular tissue, laminated tendon, dermis, costal cartilage or auricular cartilage. ${ }^{10-14}$ As well as the inevitable morbidi- 
ganando más adeptos. Entre los tejidos descritos para sustituir al menisco articular cabe citar fascia lata, tejido muscular, tendón laminado, dermis, cartílago costal o cartílago auricular. ${ }^{10-14}$ Además de la inevitable morbilidad en la zona dadora, se han descrito complicaciones con estos injertos, algunas tan severas como el desarrollo de degeneración quística en la vecindad de la base del cráneo tras el empleo de injertos dérmicos. ${ }^{15}$ Otras desventajas de los autoinjertos vienen derivadas de su variable capacidad de supervivencia en el seno de una cavidad cerrada como es la ATM, o su dudosa capacidad para soportar las fuerzas a que son sometidos por la función masticatoria.

A caballo entre los materiales aloplásticos y los injertos autólogos para reemplazar al disco articular se situaría la dura liofilizada, un material homólogo que fue objeto de esperanzadores estudios, 16 pero del que tenemos escasas referencias en la bibliografía reciente. De forma similar se ha indicado la utilización de cartílago liofilizado como material de reemplazo del disco articular de la ATM. ${ }^{17}$

Las nuevas tecnologías basadas en la ingeniería tisular permiten desarrollar tejido cartilaginoso que puede tener numerosas aplicaciones en reconstrucción de la región de cabeza y cuello, incluido la sustitución del disco articular. ${ }^{18}$

En cuanto al manejo quirúrgico de la musculatura masticatoria, algunos autores proponen la miotomía de pterigoideo lateral y su reinserción en el cuello del cóndilo, por debajo del nivel de la condilectomía, para conseguir una mayor restauración de la función articular. ${ }^{19}$ Con esta técnica se han descrito mejores resultados en parámetros importantes como apertura interincisal y los movimientos de lateralidades y protrusiva.

\section{Injertos autólogos para la reconstrucción de defectos condilares}

En la literatura médica encontramos numerosas publicaciones que determinan las ventajas de reconstruir los defectos óseos mediante injertos autólogos. En la reconstrucción de la ATM se han utilizado varios tipos de injertos autógenos: costocondral, ${ }^{20-22}$ esternoclavicular, ${ }^{23,24}$ peroneo, ${ }^{25}$ tibial, cresta ilíaca, ${ }^{26}$ calota craneal, ${ }^{27} \mathrm{o}$ metatarsiano. ${ }^{28,29}$ Sin duda, el más utilizado tradicionalmente por los cirujanos orales y maxilofaciales ha sido el injerto costocondral. ${ }^{30}$

El injerto costocondral es el tejido autólogo más aceptado tradicionalmente en reconstrucción de ATM. Inicialmente descrito por Gillies en 1920,31 la utilización del componente cartilaginoso asociado al hueso costal en artroplastia temporomandibular fue popularizada por Longacre y Gilby en la década de los 50.32,33 Las ventajas descritas por MacIntosh, ${ }^{34}$ son su compatibilidad biológica, sencillez de trabajo, accesibilidad, adaptabilidad funcional, versatilidad y mínima morbilidad adicional para el paciente. El potencial de crecimiento del injerto costocondral, debido a la incorporación de centros de crecimiento en el trasplante, ${ }^{35}$ determina su aplicación ideal en reconstrucción de la ATM en niños. $36-38$

Con respecto a otros injertos autólogos, las ventajas del injerto costocondral residen en una baja incidencia de complicaciones y de morbilidad en la región torácica, su adaptabilidad al lecho mandibular, y, especialmente, la incorporación de un cabezal de tejido ty of the donor site, complications with these grafts have been described, some so severe such as the development of cystic degeneration in the area of the skull base following the use of dermal grafts. ${ }^{15}$ Other disadvantages of autografts are derived from their variable survival capacity in the sinus of a closed cavity such as the TMJ, or their dubious ability to support the forces of masticatory function.

Straddled between alloplastic material and autogenous grafts in the replacement of the articular meniscus is lyophilized dura, a homologous material that was the object of encouraging studies, 16 but about which there is very little in recent bibliography. Similarly the use of lyophilized cartilage has been reported as replacement material for the articular meniscus of the TMJ. ${ }^{17}$

New technologies based on tissue engineering have permitted the development of cartilaginous tissue, which can be used, in a number of ways in the reconstruction of the head and neck, and also in the substitution of joint discs. ${ }^{18}$

With regard to the surgical manipulation of mastication muscles, some authors suggest lateral pterygoid myotomy and its reattachment to the condylar neck, below the level of the condylectomy, in order to achieve a greater restoration of joint function. ${ }^{19}$ With this technique better results have been reported in important parameters such as in interincisor opening and lateral and protrusive movements.

\section{Autogenous grafts for \\ the reconstruction of condyle defects}

In the medical literature we find numerous publications, which advocate the advantages of reconstructing bone defects by means of autogenous grafts. In TMJ reconstruction various types of autogenous grafts have been used: costochondral, 20-22 sternoclavicular, ${ }^{23,24}$ fibular, ${ }^{25}$ tibial, iliac crest,26 cranial calotte, 27 or metatarsal. 28,29 However, traditionally the most used by maxillofacial surgeons has been the costochondral graft. ${ }^{30}$

The costochondral graft is autogenous tissue, which is traditionally the most accepted in TMJ reconstruction. Initially described by Gillies in 1920,31 the use of the cartilaginous component associated with the costal bone in temporomandibular arthroplasty was made popular by Longacre and Gilby in the 50's decade. ${ }^{32,33}$ The advantages described by McIntosh ${ }^{34}$ are biological compatibility, simple work technique, accessibility, functional adaptability, versatility, and minimum additional morbidity for the patient. The growth possibility of the costochondral graft, due to the incorporation of growth centres in the transplant, 35 makes its application in child TMJ reconstruction ideal.

With regard to other autogenous grafts, the advantages of costochondral grafts reside in a low complication and morbidity incidence in the thorasic area, its adaptability to the mandibular bed, and especially the incorporation of a cartilaginous tissue pad which favours morphological and func- 
cartilaginoso que favorece esta adaptación morfológica y funcional y reduce la aparición de posteriores anquilosis. Por otra parte, a pesar de ser un injerto no vascularizado, el injerto costocondral parece tener escasa tendencia a reabsorción, e incluso en muchas ocasiones se hace más grande y resistente con el tiempo, a veces comprometiendo el resultado final por una excesiva longitud de la rama ascendente mandibular. ${ }^{39}$ Sin embargo, otros autores prefieren otras alternativas reconstructivas debido a la baja calidad del hueso cortical y medular del injerto costocondral, la flexibilidad y elasticidad del hueso, su facilidad de deformación al ser sometido a carga continua causando alteraciones oclusales, la posible separación del hueso y cartílago del injerto, su potencial fractura y su crecimiento impredecible. ${ }^{24,40}$

Entre las potenciales complicaciones descritas destacan el riesgo de fractura del injerto, infección con reabsorción parcial o total del mismo, morbilidad en la zona dadora, ${ }^{41}$ la variable capacidad de crecimiento del injerto ${ }^{39} y$, especialmente, la posible recidiva de la anquilosis. ${ }^{42}$ Esta anquilosis posterior a injerto costocondral es poco frecuente y en la mayoría de las ocasiones acontece en casos reconstruidos por anquilosis previa. Los tejidos de interposición descritos en la literatura para minimizar la reanquilosis son múltiples, incluídos músculos temporal, cartílago, fascia, grasa, dermis, o piel total. ${ }^{10,14,43-46}$

En la literatura se encuentran algunas controversias sobre el método de adaptación del injerto y su fijación. ${ }^{47-49}$ Aunque algunos autores prefieren la utilización de miniplacas para fijar el injerto, incluso realizando una fractura en tallo verde en el mismo para incrementar su adaptación a la rama ascendente mandibular y a la fosa glenoidea, 50 la fijación del mismo con tornillos bicorticales parece ser igualmente adecuada (Figs. 1 y 2). ${ }^{51}$

Algunos autores consideran que el injerto esternoclavicular ofrece ventajas significativas al ser embriológica e histológicamente similar al cóndilo mandibular y en cuanto a su potencial de

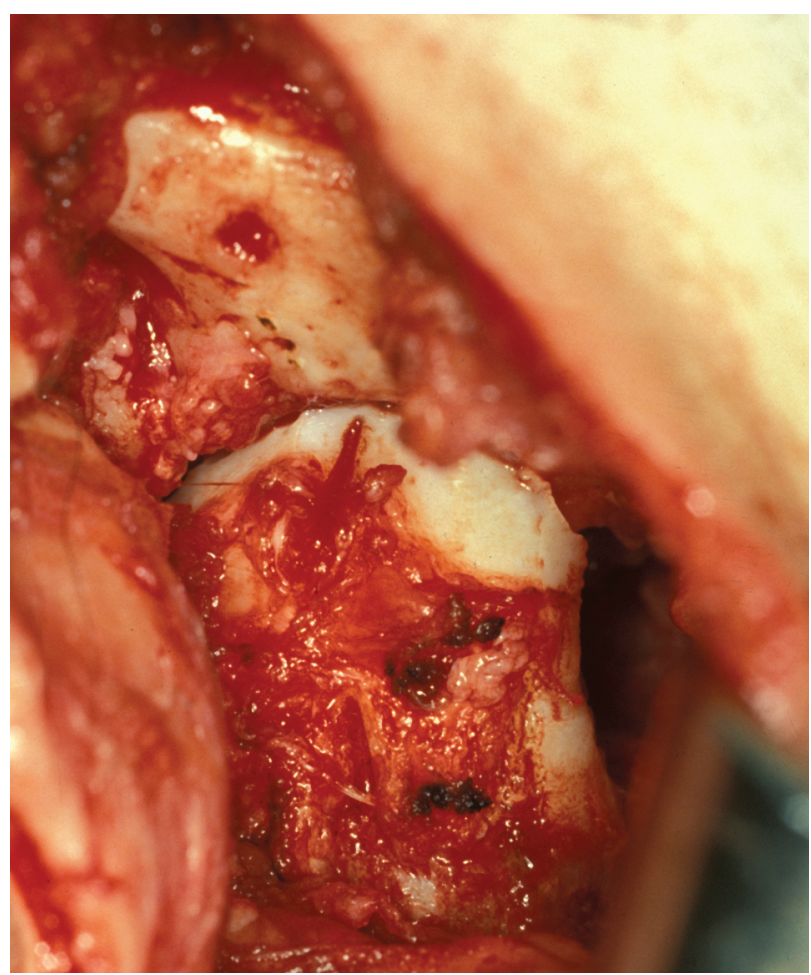

Figura 1. Remodelación y adaptación del injerto costocondral al defecto condilar.

Figure 1. Remodelling and adapting the costochondral graft to the condylar defect.

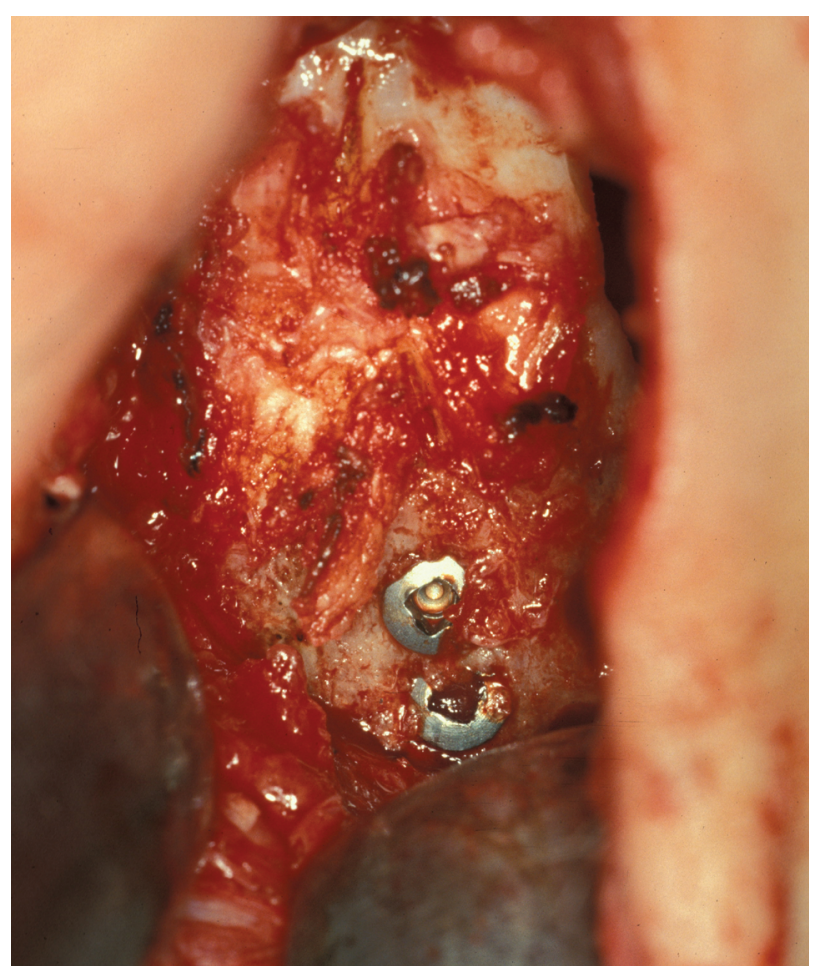

Figura 2. Fijación del injerto costocondral al muñón condilar residual mediante tornillos bicorticales.

Figure 2. Fixation of the costochondral graft to the remaining condylar stump with bi-cortical screws. tional adaptation and reduces the later onset ankylosis. On the other hand, despite it being a non-vascularized graft, the costochondral graft appears to have less tendency to reabsorb, and on several occasions it has, with time, become larger and more resistant, even affecting the final result because of the excessive length of the ascending mandibular branch. ${ }^{39}$ However, other authors prefer other reconstruction alternatives due to the inferior quality of the cortical and medical bone of the costochondral graft, the flexibility and elasticity of the bone, the facility for deformation on being subjected to continuous stress which gives rise to occlusal alterations, the possible separation of the bone and the cartilage of the graft, its possible fracture and unpredictable growth. 24,40 Among potential complications described, of note is the risk of fracture of the graft, infection with partial or total re-absorption of itself, morbidity of the donor site, ${ }^{41}$ the variable capacity of growth of the graft, ${ }^{39}$ and especially the possibility of renewed ankylosis. ${ }^{42}$ Ankylosis following a costochondral graft is not very frequent, and in the majority of cases it occurs after a reconstruction carried out because of previous ankylosis. The interposition tissues described in the literature to minimize re-ankylosis are multiple, including temporal muscles, cartilage, fascia, fat, dermis, or skin (all of itNT). 10,14,43-46

In the literature there is certain controversy over the method of adaptation of the graft and its fixation. ${ }^{47-49}$ 
crecimiento adaptable a la región del cóndilo mandibular.23,40 Wolford y $\operatorname{cols}^{24}$ defienden el injerto esternoclavicular obtenido de la mitad craneal de la clavícula contralateral. Utilizando como criterios de éxito terapéutico la reducción o eliminación del dolor, la obtención de una oclusión estable y la movilidad adecuada de los maxilares, con una apertura interincisal superior a $30 \mathrm{~mm}$, estos autores encuentran mejores resultados en casos que no han sido previamente reconstruidos con sistemas protésicos ni presentan patología inflamatoria articular. En estos casos, su éxito terapéutico se cifra en un $93 \%$ de los pacientes. Incluso se ha descrito su indicación para la reconstrucción completa de la ATM incluyendo una porción del manubrio esternal como sustituto de la porción temporal de la articulación. ${ }^{23}$

Algunos autores preconizan el empleo de injerto esternoclavicular para lareconstrucción mandibular en pacientes en crecimiento amparándose en su capacidad de crecimiento compatible con la rama ascendente mandibular. Sin embargo, otros consideran que no existen diferencias significativas en potencial de crecimiento mandibular entre reconstrucciones con injertos esternoclaviculares y costocondrales. ${ }^{40,52}$

Por el contrario, otros autores consideran que la complejidad quirúrgica del injerto esternoclavicular y su potencial morbilidad en la zona dadora han sido factores desalentadores para su aplicación generalizada como sustitutos del cóndilo mandibular. ${ }^{1}$ En la zona dadora clavicular se ha descrito aproximadamente un $10 \%$ de fracturas claviculares de las cuales más del $50 \%$ de los casos requirieron reducción abierta. ${ }^{24}$

Los injertos metatarsianos tienen un largo historial como sustitutos condilares, desde su primera descripción por Bardenheuer en 1906. ${ }^{53}$ Permiten una excelente adaptación anatómica a la fosa temporal, pero la ausencia de cartílago adicional favorece el desarrollo de anquilosis. Aunque conservan un potencial de crecimiento epifisario, su adaptación al crecimiento y función mandibular no parece ser demasiado adecuada. Los estudios de Dingman y Grabb de mediados de los 60,28 demostraron una reabsorción progresiva de los metatarsianos no vascularizados injertados para reconstrucción condílea en 5 pacientes, con la consiguiente retrognatia y laterodesviación mandibular. Ello llevó al abandono de la técnica. Posteriomente, en 1986, Datillo y cols ${ }^{54}$ publicaron la reconstrucción exitosa de una ATM con la segunda articulación metatarso-falángica libre vascularizada, pediculada en la arteria dorsalis pedis y sus venas comitantes. Otros trabajos posteriores, a pesar de realizarse con una muestra reducida de casos, confirman la indicación adecuada de esta técnica reconstructiva en defectos condilares, con excelentes resultados estéticos y funcionales, incluso con seguimientos a largo plazo, 55,56 y en pacientes en crecimiento. ${ }^{57}$

La irrupción de los mecanismos de distracción osteogénica ha supuesto un gran avance en las opciones reconstructivas de cabeza y cuello. Aunque sus posibilidades rebasen los objetivos del presente artículo, resulta imposible plantear cualquier reconstrucción ósea en la actualidad sin recapacitar sobre las prestaciones que aportan los distractores de que disponemos en el mercado. En la literatura médica se pueden encontrar numerosas referencias sobre transporte óseo y distracción de rama ascendente mandibular para reemplazar un cóndilo, ${ }^{88-60}$ e incluso distracción de injertos autólo-
Even though some authors prefer the use of mini-plates for the fixation of grafts, including making a "green stick" fracture so as to increase adaptation to the ascending mandibular branch and glenoid fossa, fixation with bicortical screws is equally suitables1 (Figs. 1 and 2).

Some authors consider that the sternoclavicular graft offers significant advantages as it is embryologically and histologically similar to the mandibular condyle, and with regards to potential growth, it is adaptable to the mandibular condyle area. ${ }^{23,40}$ Wolford et a ${ }^{24}$ defend the sternoclavicular graft obtained from the cranial half of the contralateral clavicle. Using the criteria that therapeutic success consists in the reduction or elimination of pain, obtaining stable occlusion and adequate mobility of the jaw, with an inter-incisor opening superior to $30 \mathrm{~mm}$, these authors find better results in cases not previously reconstructed with prosthetic systems in which there is neither inflammatory pathology of the joint. In these cases, therapeutic success is rated as $93 \%$ of patients. Complete reconstruction of the TMJ with a portion of the sternal manubrium to substitute the portion of temporal bone of the joint has even been described. ${ }^{23}$

Some authors favour the use of the sternoclavicular graft for the reconstruction of the mandible for growing patients, defending that growth capacity is compatible with the ascending branch of the mandible. However, others consider that there are no significant differences in the potential for mandibular growth between reconstructions with sternoclavicular and with costochondral grafts. 40,52

On the other hand, other authors consider that surgical complexity of the sternoclavicular graft, and potential morbidity of the donor site, have been discouraging with regard to their application in general as substitutes for the mandibular condyle. In the clavicular donor site, 10\% clavicular fractures have been reported, $50 \%$ of which required open reduction. ${ }^{24}$

Metatarsal bone grafts have a long history as condyle substitutes, since Bardenheuer first described them in 1906.53 They permit an excellent anatomical adaptation to the temporal fossa, but the absence of cartilage favours the development of ankylosis. Even though they conserve a potential for epiphysarian growth, their capacity for adapting to the growth and function of the mandible does not appear to be adequate. Studies by Dingman and Grabb in the mid-sixties ${ }^{28}$ showed that there was a progressive re-absorption of non-vascularized metatarsian grafts used in the reconstruction of the condyle in five patients, with the resulting retrognathia and lateral deviation of the mandible. This led to the technique being abandoned. Later, in 1986, Datillo et a ${ }^{54}$ published the successful reconstruction of the TMJ with the second, free, vascularized metatarso phalangeal joint, pedicled to dorsalis pedis artery and comitant veins. Other later works, despite only being in a reduced number of cases, confirmed the suitability of this reconstruction technique in condyle defects, with excellent aesthetic and functional results, including long term follow-up cases 55,56 and growing patients. ${ }^{57}$ 
gos previamente utilizados como refinamiento de resultados estéticos y funcionales. ${ }^{61}$

Las principales desventajas que se atribuyen a los injertos autólogos en reconstrucción de la ATM vienen derivadas de la indefectible morbilidad adicional en las zonas dadoras y de la variabilidad de su comportamiento biológico con respecto a capacidad de reabsorción, desarrollo de anquilosis y crecimiento del injerto. ${ }^{34}$ Sin embargo, su mayor desventaja probablemente sea que retrasan el inicio de la rehabilitación de la articulación en el postoperatorio. 5,62

\section{El papel de la reconstrucción microquirúrgica en la ATM}

En la actualidad, la transferencia de tejido autólogo vascularizado basándose en técnicas microquirúrgicas es una modalidad terapéutica ampliamente aceptada en nuestra región anatómica. Los estudios basados en la evidencia y la experiencia clínica sugieren que la morbilidad asociada es relativamente baja y los riesgos son aceptables por parte de los pacientes. En este contexto, las principales ventajas de la reconstrucción microquirúrgica temporomandibular son la mejor estabilidad tridimensional a largo plazo, la versatilidad reconstructiva y la mínima capacidad de desarrollar complicaciones. ${ }^{63}$

Previamente ha sido mencionada la reconstrucción de la ATM con metatarsiano vascularizado. En 2003, Landa y cols. ${ }^{56}$ publican excelentes resultados en un seguimiento a largo plazo de 5 pacientes reconstruidos con la segunda articulación metatarso-falángica microvascularizada.

Aunque existen descritas reconstrucciones microquirúrgicas de ATM con cresta ilíaca, 64,65 el colgajo libre más frecuentemente utilizado en estas reconstrucciones es el peroné. ${ }^{25,66}$ En nuestra práctica clínica, la mayoría de los casos no corresponden a reconstrucciones específicas de ATM, sino a reconstrucciones de defectos mandibulares amplios que involucran esta articulación (Fig. 3). La filosofía de reconstruir funcionalmente la misma con interposición de tejidos blandos y fijación de estructuras musculares al neocóndilo permite la obtención de mejores resultados funcionales a largo plazo. Los sistemas de anclaje tipo Mitek ${ }^{\circledR}$ han demostrado su utilidad en este tipo de reconstrucciones (Figs. 4, 5 y 6).

Asimismo, se encuentra en la literatura excelentes resultados con colgajo microvascularizado de peroné en niños. ${ }^{67}$ operative rehabilitation of the joint is delayed. 5,62

The invasion by osteogenic distraction mechanisms has meant a great advance in the reconstructive options for the head and neck. Even though the possibilities go beyond the scope of this article, considering bone reconstruction at the present time is impossible, without giving some thought to the uses, which the distractors on the market give us. Numerous references can be found in the medical literature on bone transport and distraction of the ascending mandibular branches to replace a condyle, ${ }^{58-60}$ and even on distraction of autogenous grafts previously used for refinement of aesthetic and functional results. ${ }^{61}$

The principal disadvantages that are attributed to autogenous grafts in reconstruction of the TMJ are derived from the addition of inevitable donor site morbidity, and of the variableness of biological behaviour with regard to reabsorption capacity, development of ankylosis, and growth of the graft. ${ }^{34}$ However, the greatest disadvantage is probably that the start of post-

\section{The role of microsurgery in TMJ reconstruction}

At the present time, the transfer of vascularized, autogenous tissue based on microsurgery techniques, is a form of treatment widely accepted in our anatomic area. Studies based on clinical evidence and experience suggest that associated morbidity is relatively low and the risks, from the patient's point of view, are acceptable. In this sense, the principal advantages of microsurgical temporomandibular reconstruction are the best tri-dimensional stability in the long term, reconstructive versatility and the minimum capacity for developing complications. ${ }^{63}$

The reconstruction of the TMJ with vascularized metatarsal has been mentioned previously. In 2003, Landa et als6 published excellent results in a long-term following of 5 patients reconstructed with the second microvascularized metatarso phalangeal joint. 
Aunque la impredecible tendencia a reabsorción y cambios degenerativos a largo plazo son desventajas clásicamente atribuídas a los injertos libres no microvascularizados, también se encuentra en la literatura referencias sobre alteraciones morfológicas en seguimientos prolongados de injertos óseos vascularizados. Guyot y cols ${ }^{68}$ encuentran remodelación del neocóndilo peroneo en seguimientos radiológicos a largo plazo, consistente en redondeamiento y estrechamiento del muñón.

\section{Luxación recidivante de ATM}

Se han descrito dos principales grupos de técnicas quirúrgicas para los casos de luxación recidivante de ATM: un primer grupo de cirugías dirigido a eliminar los posibles determinantes que inducen al bloqueo del cóndilo mandibular por delante de la eminencia articular; y un segundo grupo que persigue minimizar las excursiones del cóndilo mandibular durante la apertura oral. En este artículo sobre reconstrucción de la ATM mediante injertos autólogos nos referiremos a aquellas técnicas quirúrgicas destinadas a crear un obstáculo para la translación del cóndilo mandibular durante la apertura oral mediante un incremento de altura de la eminencia temporal. Se realizaría mediante una osteotomía glenotemporal e interposición de injerto inlay en la eminencia articular, técnica popularizada por Norman. ${ }^{69}$ Aunque se han descrito excelentes resultados con materiales aloplásticos, 70 las ventajas de los tejidos autólogos se hacen igualmente presentes en estos casos. La inmensa mayoría de los autores defienden el empleo de injertos de hueso obtenido de la vecina región temporoparietal, con la ventaja adicional de que se aprovecha la misma incisión quirúrgica (Figs. 7 y 8). ${ }^{71,72} \mathrm{~A}$ pesar de ello, otros autores prefieren el empleo de injertos de cresta iliaca. ${ }^{73}$

\section{Discusión}

Las intervenciones quirúrgicas sobre la articulación témporomandibular tienen dos objetivos principales: restaurar la anatomía normal de la articulación y descomprimir las estructuras articulares. the fibular condyle. ble.

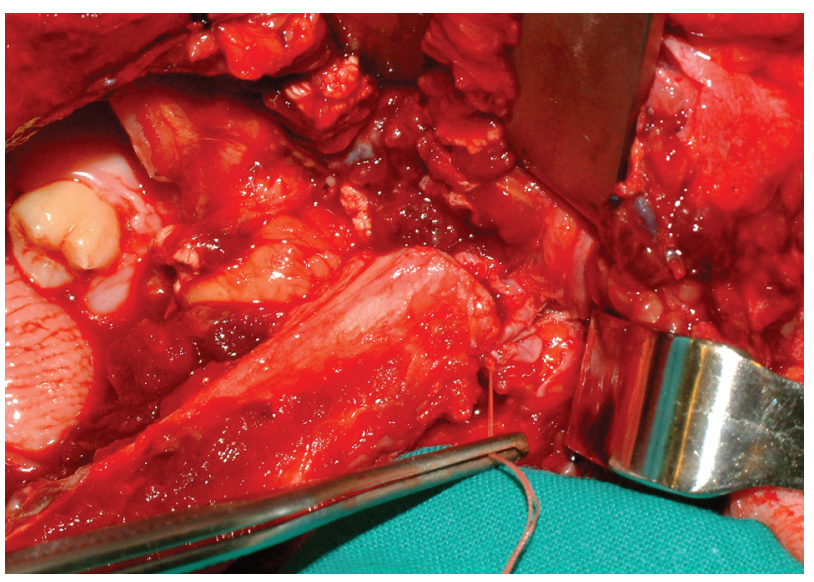

Figura 5. Reconstrucción de tejidos blandos articulares y fijación de los mismos al cóndilo peroneo.

Figure 5. Reconstruction of articular soft tissue and its fixation to

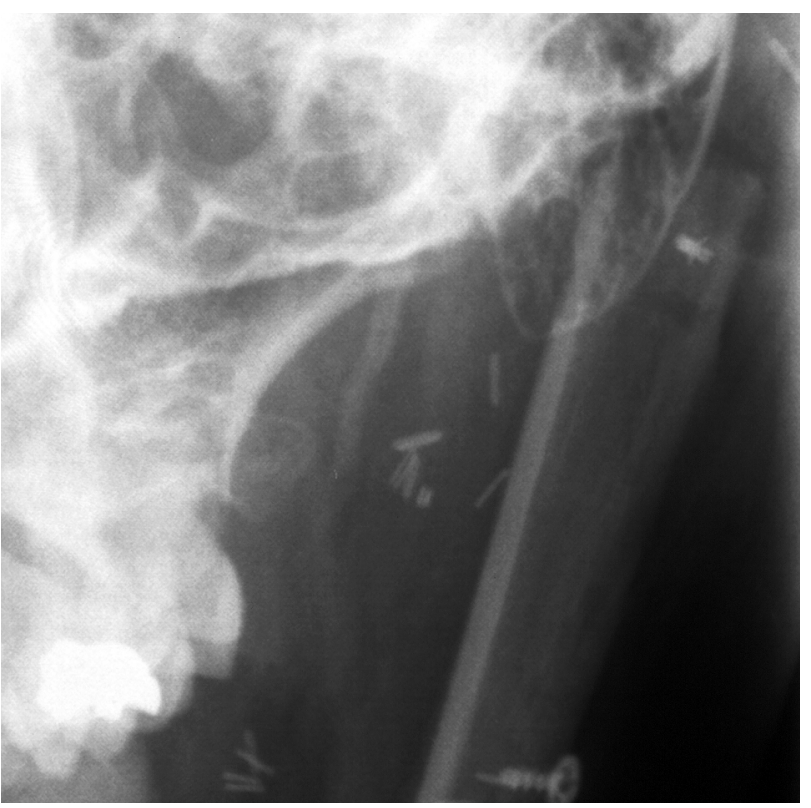

Figura 6. Visión parcial de ortopantomografía de control en la que se objetiva la posición del anclaje de los tejidos blandos articulares. Figure 6. Partial vision of the orthopantomography of control in which the position of the anchor in the articular soft tissue is visi-

ing and thinning of the stump.

\section{Recurrent dislocation of the TMJ}

Two main groups of surgical techniques have been described for cases of recurrent dislocation of the TMJ: the first group of surgery designed to eliminate the possible factors which lead to the condyle blocking before the articular eminence and a second group which aimed to minimize the excursions of the mandibular condyle during oral aperture.

Even though microsurgical reconstructions of the TMJ have been described with the iliac crest, 64,65 the free flap most frequently used in these reconstructions is the fibula. In our clinical practice, the majority of cases do not concern specific TMJ reconstructions, rather a wide range of mandibular defects, which involve this joint (Fig. 3). The philosophy behind functional reconstruction with the insertion of soft tissue and the fixation of muscular structures to the neocondyle, allows better functional results to be achieved in the long term. Mitek ${ }^{\circledR}$ type anchor systems have proved their usefulness in this type of reconstruction (Figs. 4,5 and 6).

Similarly, excellent results have been found in the literature with microvascularized fibular flaps in children. ${ }^{67}$ Even though there is an unpredictable tendency for re-absorption and degenerative changes in the long term, disadvantages classically attributed to free nonmicrovascularized grafts; there are also references in the literature to morphological alterations in longer follow-up studies of vascularized bone grafts. Guyot et al68 found that the fibular neo-condyle in radiological long-term follow-ups remodelled itself in terms of round- 
Ambos requerimientos deben conllevar una situación clínica de ausencia de dolor y recuperación de la función articular. Estos objetivos finales deben estar muy presentes a la hora de plantear una opción reconstructiva de la ATM.

En la actualidad no existen dudas sobre los excelentes resultados que se obtienen con injertos autólogos en reconstrucción de ATM. Sin embargo, se ha descrito que la incidencia de dolor y especialmente recidiva de anquilosis y complicaciones, es mayor en aquellos pacientes que han sido sometidos a múltiples cirugías articulares previamente. ${ }^{74}$ Según algunos autores, el reemplazamiento total de las estructuras de la ATM por determinadas prótesis aloplásticas parece producir mejores resultados en estos casos multioperados que presentan necrosis avascular del segmento condilar. ${ }^{75-77}$ Sin embargo, otros autores proponen un abordaje escalonado utilizando tejidos autólogos como técnica reconstructiva definitiva. ${ }^{1}$

En los pacientes que fracasa el tratamiento con prótesis aloplásticas y es precisa su retirada se ha demostrado que la reacción osteoclástica persiste incluso después de retirar el implante, probablemente como respuesta a la diseminación de partículas en los tejidos blandos vecinos. ${ }^{78}$ De esta manera, se recomienda eliminar todos los tejidos patológicos contiguos antes de plantear una nueva reconstrucción. ${ }^{1}$ La inclinación natural sería hacia la colocación de una nueva prótesis. Sin embargo, algunos autores prefieren monitori-

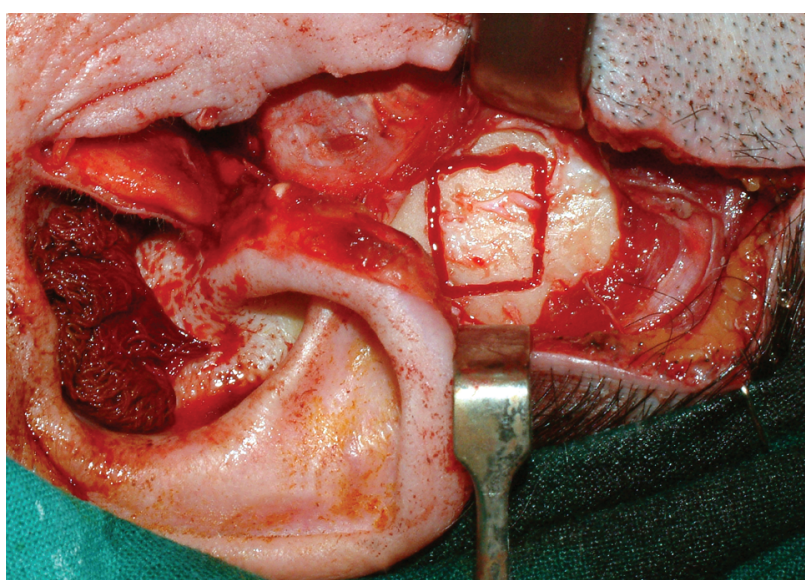

Figura 7. Toma de injerto óseo de calota temporal, aprovechando el mismo abordaje quirúrgico de la ATM.

Figure 7. Image of bone graft of temporal calotte, using the same surgical approach of the TMJ.

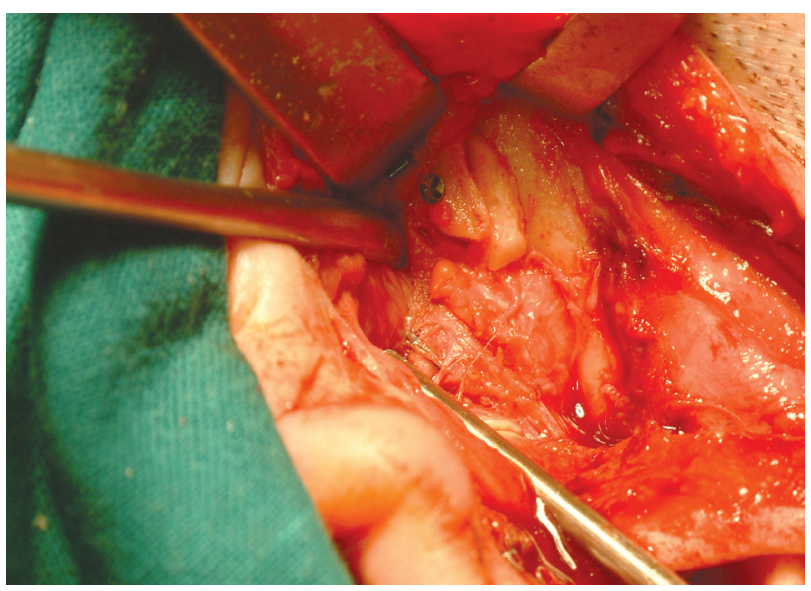

Figura 8. Interposición de injerto en la osteotomía glenotemporal para incrementar la altura de la eminencia temporal. En este caso se decidió su fijación mediante tornillo para asegurar la estabilidad del mismo.

Figure 8. Interposition of graft in the glenotemporal osteotomy so as to increase the height of the temporal eminence. In this case fixation with screws was decided so ensure stability.
In this article on reconstruction of the TMJ with autogenous grafts, we refer to those surgical techniques intended to create an obstacle for the translation of the mandibular condyle during oral aperture through augmentation of the height of the temporal eminence. This is done by means of a glenotemporal osteotomy and the interposition of an inlay graft in the articular eminence, a technique made popular by Norman. Even though excellent results with alloplastic materials 70 have been described, the advantages of autogenous tissue are equally stated in these cases. The large majority of authors defend the use of bone grafts obtained from the neighbouring temporoparietal region, with the additional advantage that the same surgical incision used 71,72 (Figs. 7 and 8). In spite of this, other authors prefer the use of grafts from the iliac crest. ${ }^{73}$

\section{Discussion}

Surgical intervention of the temporomandibular joint has two main objectives: restoration of the joint's normal anatomy, and the decompression of joint structures. zar al paciente durante al menos 12 meses, tanto clínica como radiológicamente, para valorar cualquier evidencia de progresión de la situación patológica y sólo entonces reconstruir secundariamente la ATM con injertos autólogos. ${ }^{1,34}$ Con esta filosofía de diferir la reconstrucción autógena se pretende permitir la maduración del tejido cicatricial, obtener neovascularización, restablecer el tono muscular y resolver o minimizar las respuestas inflamatorias previas. Las reintervenciones prematuras incrementarían la potencial morbilidad, la cicatrización y el riesgo de desarrollar nuevamente anquilosis.

Algunos autores consideran que las prótesis de ATM son capaces de reproducir mejor la anatomía normal de la articulación, restaurando con mayor fidelidad la dimensión vertical. ${ }^{79}$ En esto ha tenido gran influencia el reciente desarrollo de prótesis individuali-
Both requirements should lead to a clinical situation of lack of pain and the recovery of joint function. These final objectives have to be very present when considering the option of reconstruction of the TMJ.

There is no doubt at present as to the excellent results, which can be achieved with autogenous grafts in the reconstruction of the TMJ. However, what has been noted has been that the incidence of pain, especially with recurrent ankylosis and complications, is greater in those patients that have been subjected to multiple interventions of the joint. ${ }^{74}$ According to some authors, total replacement of the TMJ structures with certain alloplastic prostheses can give better results in patients that have been subjected to multiple interventions and that have avascular necrosis of the condylar 
zadas, confeccionadas a medida para cada paciente. ${ }^{80,81}$ De todas formas, los tejidos autólogos han demostrado tradicionalmente una adecuada facilidad de manejo quirúrgico para su adaptación al defecto. Incluso esta "adaptabilidad" de los injertos autólogos parece persistir espontáneamente, y una vez colocados en el lecho receptor se adaptan y remodelan adecuadamente a la función a que son sometidos. ${ }^{47}$

Otras ventajas que comúnmente se atribuyen a las prótesis de ATM se refieren a evitar la morbilidad de la zona donante, reducir el tiempo quirúrgico, permitir iniciar la rehabilitación física de forma inmediata y minimizar la posibilidad de recurrencia de anquilosis articular. Es evidente el disconfort que la reconstrucción autógena produce al paciente en la zona dadora. Sin embargo, rara vez condiciona un compromiso significativo al paciente, de forma que el balance entre beneficio y riesgo es generalmente favorable. De no ser así, es obvio que el criterio reconstructivo del cirujano debería ser diferente.

En un estudio comparativo entre injertos autólogos y prótesis aloplásticas en un grupo de pacientes con patologías similares de ATM, Saeed y cols ${ }^{82}$ encontraron excelentes resultados en parámetros subjetivos como dolor y limitación para la masticación y en parámetros objetivos como apertura interincisal. Los pacientes de ambos grupos mostraron mejoría significativa de su sintomatología. Sin embargo, el número de pacientes que requirió reintervención fue mayor en el grupo de injertos autólogos.

Las potenciales desventajas de las prótesis aloplásticas vienen determinadas fundamentalmente por su capacidad de desgaste y de fracaso del material. Al mismo tiempo, estos materiales aloplásticos pueden producir liberación de partículas que degeneren en una reacción a cuerpo extraño y desencadenar una importante actividad osteoclástica por células gigantes. El mecanismo fisiopatológico de esta reacción destructiva todavía no es conocido del todo, aunque Zardeneta y cols ${ }^{83}$ proponen la adherencia de proteínas reactivas a partículas liberadas de politetrafluoroetileno (PTFE) que desencadenan una respuesta inmune. Otros estudios han demostrado que los materiales extraños estimulan ciertas respuestas celulares de secreción de mediadores inflamatorios como la interleuquina-1 o la prostaglandina E2.84,85

En la literatura médica existe abundante documentación sobre la liberación de partículas residuales a los tejidos blandos vecinos a la prótesis, así como su diseminación a ganglios linfáticos regionales. ${ }^{75,78,86,87}$ Esta liberación de residuos parece persistir incluso después de la retirada de la prótesis. De esta forma, la actividad destructiva parece ser progresiva en el tiempo, por lo que muchos de los pacientes que todavía no la han experimentado son susceptibles de sufrir esas consecuencias devastadoras con el paso de los años. Todas estas circunstancias pueden llevar a una potencial pérdida del implante, destrucción de tejidos vecinos, deformación o reabsorción de la fosa o de la eminencia, y ello resultar en potenciales complicaciones intracraneales, o desencadenar un cambio oclusal, desplazamiento de la prótesis, o incluso fractura de la misma. ${ }^{77,88}$ Los procesos de osteólisis alrededor de los tornillos de fijación o de la propia prótesis pueden llevar a su inestabilidad y favorecer procesos de fibrosis y reabsorción de estructuras vecinas. segment. $75-77$ However, other authors propose a more spread out approach using autogenous tissue as a definitive reconstruction technique.

With patients that have experienced treatment failure with alloplastic prostheses, and removal has been necessary, it has been demonstrated that the osteoclastic reaction persists even after the removal of the implant, probably as a result of the dissemination of particles into the adjacent soft tissue. ${ }^{78}$ Because of this, eliminating all adjacent, pathological tissue is advised before planning renewed reconstruction. ${ }^{1}$ It would only be normal to be inclined towards the placement of another prosthesis. However, some authors prefer monitoring a patient during at least 12 months, clinically as well as radiologically, so as to evaluate any sign of progression of the pathological situation, and only then carry out secondary reconstruction of the TMJ with autogenous grafts. 1,34 This philosophy of delaying autogenous reconstruction allows for the maturing of scar tissue, obtaining revascularization, re-establishing muscle tone, and resolving or minimizing previous inflammatory responses. Premature re-intervention would increase potential morbidity, scarring and the risk of redevelopment of ankylosis.

Some authors consider that the TMJ prostheses are better for reproducing the normal anatomy of the joint, restoring vertical dimension with greater fidelity. ${ }^{79}$ The recent development of made-to-measure, individual prostheses for each patient ${ }^{80,81}$ has, in this respect, had a great influence. In all events, autogenous tissue has traditionally demonstrated an adequate surgical malleability regarding defect adaptation. This "adaptability" of autogenous grafts even appears to persist spontaneously, and once placed in the recipient bed, they adapt and re-mould themselves adequately to the function to which they are subjected. ${ }^{47}$

Other advantages, which are commonly attributed to the TMJ prostheses, refer to prevention of donor site morbidity, decrease in operative time, immediate initiation of physical rehabilitation and minimizing the recurrence possibility of joint ankylosis. The discomfort which autogenous reconstruction produces in the patient in the donor site is obvious. However, it rarely entails any significant predicament for the patient, and there is generally a favourable riskbenefit balance. If this is not the case, the reconstruction criteria of the surgeon should obviously be different.

In a comparative study of autogenous grafts and prostheses in a group of patients with similar pathologies of TMJ Saeed et al${ }^{82}$ found excellent results in subjective parameters such as pain and mastication limitation, and in objective parameters such as inter-incisor opening. The patients in both groups showed a significant improvement in symptomatology. However, the number of patients that needed further surgical intervention was greater in the autogenous graft group.

The potential disadvantages of alloplastic prostheses are fundamentally determined by their poor wear characteristics and material breakdown. At the same time these mate- 
Algunos autores enfatizan la inflexibilidad de estas prótesis para acomodarse a la morfología de la rama ascendente mandibular, especialmente a su longitud, y su escasa adaptabilidad a la fosa glenoidea como elemento adicional para el desarrollo de todas estas complicaciones. ${ }^{1}$ Por otro lado, su estabilidad morfológica a largo plazo contraindica su utilización en pacientes en crecimiento. ${ }^{5}$ Otras desventajas descritas para los materiales heterólogos son su capacidad de dar lugar a la formación de hueso distrófico, desarrollo de complicaciones infecciosas severas, y el incremento sustancial de los costes asociados a esta reconstrucción. ${ }^{89}$

Algunos pacientes refieren disconfort derivado de la ausencia de motilidad lateral y, con prótesis metálicas, aparición de neuralgias y trastornos sensitivos en situaciones de temperatura fría. Por el contrario, otros sistemas no metálicos confeccionados a base de derivados acrílicos o silicona, además de ser menos resistentes a las fuerzas que deben soportar, pueden favorecer el desarrollo de complicaciones en tejidos blandos como dehiscencias en piel y mucosas, o incitar respuestas inflamatorias. En casos tumorales susceptibles de recibir radioterapia se incrementa enormemente el potencial desarrollo de complicaciones debido a su imposible vascularización.

La adición de un elemento aloplástico de cavidad glenoidea en el sistema protésico de la ATM permitió una mejor relación entre las neosuperficies articulares superior e inferior, un presumible mejor funcionamiento del sistema, y una protección adicional para la cavidad craneal. Sin embargo, se incrementa la capacidad de desarrollar complicaciones infecciosas, reacciones destructivas de células gigantes, reabsorción de estructuras anatómicas y desarrollo de fibrosis restrictiva entre los implantes y los tejidos vivos. Todas estas desventajas han llevado a algunos autores a afirmar que la reconstrucción de la ATM con prótesis aloplásticas es únicamente una segunda opción en la casi totalidad de los casos.1,34

En las décadas de los 70 y 80, hemos asistido a un incremento inusitado del número de intervenciones quirúrgicas sobre la ATM. En Norteamérica ese boom quirúrgico de ATM ha sido especialmente remarcable, en base a una serie de circunstancias. Por una parte, los especialistas norteamericanos en Cirugía Oral y Maxilofacial desarrollaron un especial interés en la cirugía de ATM, probablemente debido a la formación de un excesivo número de jóvenes especialistas para las necesidades sociales de ese momento, que encontraron una excelente oportunidad para satisfacer sus expectativas profesionales e intelectuales en este tipo de cirugía. Esta circunstancia coincidió con una etapa de intenso esfuerzo comercial para la popularización del remplazamiento de las estructuras articulares por materiales aloplásticos. En tercer lugar, se asocia el consentimiento por parte de las compañías de seguros para ofrecer generosos reembolsos por este tipo de cirugía. ${ }^{34}$

Con todas estas premisas, existe una idea generalizada en la actualidad de que en esas épocas se realizaron sobreindicaciones quirúrgicas en número y en agresividad sobre la ATM, cuyas consecuencias han resultado desastrosas en no pocas ocasiones. Gran parte de esa iatrogenia ha resultado de la abusiva utilización de materiales aloplásticos para reconstrucción de la fosa glenoidea, el disco articular o el cóndilo mandibular. Resulta imposible determinar actualmente qué proporción de esa iatrogenia se hubiera evi- rials can lead to a release of particles, which set off foreign body reaction, and this can lead to important osteoclastic activity by giant cells. The physiopathological mechanism of this destructive reaction is not yet altogether comprehended, even though Zardeneta el als3 proposed that it was the adherence of reactive proteins to liberated particles of polytetrafluoroethylene (PTFE) that lead to a immunological response. Other studies have demonstrated that foreign materials stimulate certain cellular responses like the secretion of inflammatory mediators such as the interleukin -1 or prostaglandin $E-2.84,85$

There are abundant reports in the medical literature on the release of residual particles in neighbouring soft tissue next to the prostheses, as well as the dissemination of regional lymphatic ganglia. $75,78,86,87$ This liberation of residue seems even to continue following the removal of the prosthesis. In this sense, the destructive activity seems progressive over time, and many patients that have not experienced it are susceptible to suffering devastating consequences with the passing of time. All these circumstances can lead to potential loss of the implant, destruction of neighbouring tissues, deformation or re-absorption of the fossa or eminence. This can lead to potential intracranial complications, or set off an occlusal change, displacement of the prosthesis, or even its fracture. The osteolysis process around the fixation screws or around the prosthesis itself could lead to its complete instability and encourage a fibrosis process and the re-absorption of neighbouring structures.

Some authors stress the lack of flexibility of these prostheses for adapting to the morphology of the ascending mandibular branch, especially the length, and their limited adaptability to the glenoid fossa, as an additional element in the development of all these complications. ${ }^{1}$ Aside from this is its morphological long-term stability, which is not recommended in growing patients. ${ }^{5}$ Other disadvantages described of heterologous material are its capacity for causing the formation of dystrophy bone, the development of severe infectious complications, and the substantial increase in costs associated with this reconstruction. 89

Some patients report discomfort due to the absence of lateral motility, and with metal prostheses neuralgias appear and sensitivity disorders in cold temperatures. On the other hand, with other non-metallic systems made with acrylic or silicone derivatives, in addition to being less resistance to the forces have to be supported, soft tissue complications can develop such as skin and mucous dehiscence, or inflammatory responses. In the case of tumours which are likely undergo radiotherapy, the possibility of developing complications is increased enormously due to vascularization being impossible.

The addition of a glenoid cavity-like alloplastic element in the prosthetic system of the TMJ permitted a better relation between the superior and inferior joint neo-surfaces, presumably a better functioning of the system, and additional protection for the cranial cavity. However, there is an increase 
tado con la indicación más racional de la cirugía de ATM y la utilización de tejidos autólogos para su reconstrucción.

Todas estas consideraciones, junto con las particularidades histológicas y funcionales que rodean esta articulación, hacen que autores de reconocido prestigio internacional como Maclntosh, 1 limiten las indicaciones de reemplazamiento de la ATM con prótesis aloplásticas a pacientes geriáticos y a reconstrucciones temporales tras cirugía ablativa, hasta una posterior reconstrucción con injertos autógenos una vez que el potencial de recidiva patológica se ha minimizado.

Por el contrario, otros autores, ${ }^{5}$ consideran que en estas reconstrucciones complejas el objetivo primordial es restaurar la forma y la función mandibular, y que la reducción del dolor es un objetivo secundario por ser un componente intrínseco de la disfunción articular. De esta forma defienden la reconstrucción con materiales aloplásticos al proporcionar una mejor rehabilitación biomecánica, sin considerar en la misma medida la respuesta biológica a esa patología de ATM.

El cirujano minucioso debe reconocer que la reconstrucción de la ATM mediante injertos autólogos no está exenta de potenciales complicaciones y secuelas. Sin embargo, estas dificultades son más predecibles y mucho más recuperables que las secundarias a prótesis articulares.

\section{Conclusiones}

Hasta el momento, los tejidos autólogos han demostrado mejores prestaciones que las prótesis aloplásticas en la reconstrucción de la ATM. Ello no significa que los injertos y colgajos autólogos no estén exentos de complicaciones y secuelas, pero éstas son menos frecuentes y más recuperables que las provocadas por prótesis. Además, la capacidad de introducir iatrogenia adicional al paciente es claramente inferior.

En los próximos años probablemente asistiremos a tendencias reconstructivas cambiantes en función de los avances tecnológicos en biomateriales y especialmente en ingeniería tisular.90,91 Hasta la irrupción de esa revolución tecnológica que permita superar las desventajas que proporciona el uso de prótesis aloplásticas, los tejidos autógenos seguirán constituyendo la mejor opción reconstructiva en la mayor parte de los casos.

\section{Agradecimientos}

Agradecer al Dr. Martín-Granizo su amable invitación para la realización de este trabajo.

\section{Bibliografía}

1. Maclntosh RB. The use of autogenous tissues for temporomandibular joint reconstruction. J Oral Maxillofac Surg 2000;58:63-9.

2. Kent JN, Misiek DJ. Controversies in disc and condyle replacement for partial and total temporomandibular joint reconstruction. En: Worthington P, Evans in the capacity for developing infectious complications, destructive reactions of giant cells, re-absorption of anatomic structures and development of restrictive fibrosis between the implants and live tissue. All these disadvantages have led some authors to affirm that the reconstruction of the TMJ with alloplastic prostheses is only a second option in nearly all cases. 1,34

In the decade of the 70s and the 80s, we have witnessed an unusual increase in the number of surgical intervention of the TMJ. In North America this surgical boom has been especially remarkable, based on a series of circumstances. On the one hand, North American specialists in Oral and Maxillofacial surgery developed a special interest in TM] surgery probably due to the training of an excessive number of young specialists for the social needs of that moment, who found and excellent opportunity for satisfying their professional and intellectual expectations with this type of surgery. These circumstances coincided with a phase of intense commercial effort to popularise the replacement of joint structures with alloplastic material. Thirdly, there is a certain associated consensus on the part of insurance companies with regard to generous refunds for this type of surgery. ${ }^{34}$

With all these premises, there is currently a general idea that, in those times, interventions on the TMJ were too many and too aggressive, and that on many occasions there have been disastrous consequences as a result of this. Great part of that iatrogenic therapy was the result of the abuses of alloplastic materials for the reconstruction of the glenoid fossa, the articular disc or the mandibular condyle. It is currently impossible to establish just how much of that iatrogenic therapy could have been avoided with more rational indications for TMJ surgery and the use of autogenous tissue for reconstruction.

All these considerations, together with the histological and functional characteristics which surround this joint, lead authors of recognized international prestige such as McIntosh, ${ }^{1}$ to limit the indications for TMJ replacement with alloplastic prostheses to geriatric patients and to temporary reconstructions following ablative surgery, and until there is later reconstruction with autogenous grafts once the potential for a pathological relapse has been minimized.

Other authors, 5 on the contrary, consider that in complex reconstructions the primordial objective is the restoration of mandibular function and form, and that the reduction of pain is a secondary objective, as it is an intrinsic component of joint dysfunction. They defend in this way the reconstruction with alloplastic material as it allows for better bio-mechanic rehabilitation, without taking into consideration the biological response to the pathology of the TMJ to the same degree.

The meticulous surgeon has to recognise that the reconstruction of the TMJ by means of autogenous grafts is not exempt of potential complications and sequelae. However, these difficulties are more predictable and much more rectifiable than the secondary ones of joint prostheses. 
JR, editors. Controversies in oral and maxillofacial surgery. 1994;397-435. WB Saunders, Philadelphia.

3. Nelson CL, Buttrum JD. Costochondral grafting for post-traumatic temporomandibular joint reconstuction: A review of six cases. J Oral Maxillofac Surg 1989;47:1030-6; disc. 1037-8.

4. Mercuri LG. Considering total temporomandibular joint replacement. Cranio 1999;17:44-8.

5. Mercuri LG. The use of alloplastic prostheses for temporomandibular joint reconstruction. J Oral Maxillofac Surg 2000;58:70-5.

6. Rippert ET, Flanagan TJ, Middlebrooks ML. New design for Silastic implants in temporomandibular joint surgery. J Oral Maxillofac Surg 1986;44:163-4.

7. Gundlach KK. Long-term results following surgical treatment of internal derangement of the temporomandibular joint. / Craniomaxillofac Surg 1990;18:2069.

8. Westesson PL, Eriksson L, Lindstrom C. Destructive lesions of the mandibular condyle following discectomy with temporary silicone implant. Oral Surg Oral Med Oral Pathol 1987;63:143-50.

9. Kaplan PA, Ruskin JD, Tu HK, Knibbe MA. Erosive arthritis of the temporomandibular joint caused by Teflon-Proplast implants: Plain film features. Am J Roentgenol 1988; 151:337-9.

10. Narang R, Dixon RA. Temporomandibular joint arthroplasty with fascia lata. Oral Surg 1975;39:45-50.

11. Albert TW, Merrill RG. Temporalis myofascial flap for reconstruction of the temporomandibular joint. Oral Maxillofac Surg Clin North Am 1989;1:341.

12. Meyer RA. The autogenous dermal graft in temporomandibular joint disc surgery. J Oral Maxillofac Surg 1988;46:948-54.

13. loannides $C$, Freihofer HP. Replacement of the damaged interarticular disc of the TMJ. / Craniomaxillofac Surg 1988;16:273-8.

14. Ioannides C, Maltha JC. Replacement of the interarticular disc of the craniomandibular joint with fresh autogenous sternal or auricular cartilage. An experimental study in guinea pigs. / Craniomaxillofac Surg 1988;16:343-9.

15. Bonnington $G$, Langan $M$, Joy ED Jr. Epithelial inclusion cyst in the temporomandibular joint after a dermal graft. J Oral Maxillofac Surg 1987;45:705-7.

16. Timmel R, Grundschober F. The interposition of lyodura in operations for ankylosis of the temporomandibular joint: An experimental study using pigs. J MaxiIlofac Surg 1982;10:193-9.

17. Ioannides C, Maltha JC. Lyophilized auricular cartilage as a replacement for the interarticular disc of the craniomandibular joint. An experimental study in Guinea pigs. / Cranio-Max-Fac Surg 1988;16:295-300.

18. Puelacher WG, Wisser J, Vacanti CA, Ferraro NF, Jaramillo D, Vacanti JP. Temporomandibular joint disc replacement made by tissue-engineered growth of cartilage. J Oral Maxillofac Surg 1994;52:1172-7.

19. Collins CP, Wilson KJ, Collins PC. Lateral pterygoid myotomy with reattachment to the condylar neck: An adjunct to restore function after total joint reconstruction. Oral Surg Oral Med Oral Pathol Oral Radiol Endod 2003;95:6723.

20. Maclntosh RB, Henny FA. A spectrum of application of autogenous costochondral grafts. J Maxillofac Surg 1977;5:257-67.

21. Politis C, Fossion E, Bossuyt $M$. The use of costochondral grafts in arthroplasty of the temporomandibular joint. / Craniomaxillofac Surg 1987;15:345-54.

22. Obeid G, Guttenberg SA, Connole PW. Costochondral grafting in condylar replacement and mandibular reconstruction. J Oral Maxillofac Surg 1988;46:177-82.

23. Snyder CC, Levine GA, Dingman DL. Trial of a sternoclavicular whole joint graft as a substitute for the temporomandibular joint. Plast Reconstr Surg 1971;48: 447-52.

\section{Conclusions}

Autogenous tissue has to date given better service and versatility than alloplastic prostheses in the reconstruction of TMJ. This does not signify that autogenous grafts and flaps are not exempt from complications and sequelae, but these are less frequent and more rectifiable than those caused by prostheses. Also, the possibility for introducing additional complications for the patient is clearly inferior.

Over the next years we will probably witness changing reconstructive tendencies in conjunction with technological advances in biomaterials and in tissue engineering..$^{90,91}$ Until this technological breakthrough arrives, which will allow us to overcome the disadvantages of using alloplastic prostheses, autogenous tissue will continue being the better reconstructive option in a greater proportion of cases.

\section{Acknowledgements}

Our thanks to Dr. Martin-Granizo for his kind invitation to carry out this work. 
24. Wolford LM, Cottrell DA, Henry C. Sternoclavicular grafts for temporomandibular joint reconstruction. J Oral Maxillofac Surg 1994;52:11928.

25. Celebioglu S, Unlu RE, Kocer U, Sensoz O, Mengi AS. Reconstruction of mandible with fibula free flap. Microsurgery 1988;18:156-9.

26. Matukas VJ, Szymela VF, Schmidt JF. Surgical treatment of bony ankylosis in a child using a composite cartilage-bone iliac crest graft. J Oral Surg 1980;38: 903-5.

27. Lee JJ, Worthington P. Reconstruction of the temporomandibular joint using calvarial bone after a failed Teflon-Proplast implant. / Oral Maxillofac Surg 1999; 57:457-61.

28. Dingman RO, Grabb WG. Reconstruction of both mandibular condyles with metatarsal bone grafts. Plast Reconstr Surg 1964;34:441-51.

29. Glahn MT, Winther JE. Metatarsal transplants as replacement for lost mandibular condyle (3 years follow-up). Scand J Plast Reconstr Surg 1967;1:97-100.

30. Lindqvist C, Pikahari A, Tasanen A, Hampf G. Autogenous costochondral grafts in temporomandibular joint arthroplasty. A survey of 66 arthroplasties in 60 patients. J Maxillofac Surg 1986;14:143-9.

31. Gillies HD. Plastic surgery of the face. Oxford University Press. London, 1920.

32. Longacre JJ, Gilby RF. The use of autogenous cartilage graft in arthroplasty for true ankylosis of the temporomandibular joint. Plast Reconstr Surg 1951;7:271-87.

33. Longacre JJ, Gilby RF. Further observations on the use of autogenous cartilage graft in arthroplasty of the temporomandibular joint. Plast Reconstr Surg 1952; 10:238-47.

34. Maclntosh RB. The case for autogenous reconstruction of the adult temporomandibular joint. En: Worthington P, Evans JR, eds: Controversies in Oral \& Maxillofacial Surgery 1994;356-80. WB Saunders. Philadelphia.

35. Ware WH, Brown SL. Growth centre transplantation to replace mandibular condyles. J Maxillofac Surg 1981;9:50-8.

36. Figueroa AA, Gans B], Pruzansky S. Long term follow up of a mandibular costochondral graft. Oral Surg Oral Med Oral Pathol 1984;58:257-68.

37. Wen-Ching Ko E, Huang CS, Chen YR. Temporomandibular joint reconstruction in children using costochondral grafts. J Oral Maxillofac Surg 1999;57:789-98.

38. Posnick JC. Surgical management of temporomandibular joint ankylosis in the pediatric population. Plast Reconstr Surg 1993;91:791-8.

39. Link JO, Hoffman DC, Laskin DM. Hyperplasia of a costochondral graft in an adult. J Oral Maxillofac Surg 1993;51:1392-4.

40. Ellis E, Carlson DS. Histologic comparison of the costochondral, sternoclavicular, and temporomandibular joints during growth in Macaca mulatta. J Oral Maxillofac Surg 1986;44:312-21.

41. Ohara K, Nakumara K, Ohta E. Chest wall deformities and thoracic scoliosis after costal cartilage graft harvesting. Plast Reconstr Surg 1997;99:1030-6.

42. Saeed NR, Kent JN. A retrospective study of the costochondral graft in TMJ reconstruction. Int J Oral Maxillofac Surg 2003;32:606-9.

43. Risdon F. Ankylosis of temporomandibular joint. J Am Dent Assoc 1934;21:1933.

44. Feinberg S, Larsen P. The use of a pedicled temporalis muscle-pericranial flap for replacement of the TMJ disc: Preliminary report. J Oral Maxillofac Surg 1989; 47:142-6.
45. Georgiade N, Altany F, Pickrell K. An experimental and clinical evaluation of autogenous dermal grafts used in the treatment of TMJ ankylosis. Plast Reconstr Surg 1957;19:321-36.

46. Chossegros C, Guyot L, Cheynet F, Blanc JL, Gola R, Bourezak Z, Conrath J. Comparison of different materials for interposition arthroplasty in treatment of temporomandibular joint ankylosis surgery. Long-term follow-up in 25 cases. Br J Oral Maxillofac Surg 1997;35:157-60.

47. Lindqvist C, Jokinen J, Pauukku P, Tasanen A. Adaptation of autogenous costochondral grafts used for temporomandibular joint reconstruction: A long-term clinical and radiologic follow-up. J Oral Maxillofac Surg 1988;46:465-70.

48. Mosby EL, Hiatt WR. A technique of fixation of costochondral grafts for reconstruction of the temporomandibular joint. / Oral Maxillofac Surg 1989;47:209-11.

49. Evans GR, Clark N, Manson PN. Technique for costochondral graft placement. J Craniofac Surg 1994;5:340-3.

50. Monje F, Martín-Granizo R. The "green stick" fracture technique for adaptation and fixation of costochondral grafts. J Oral Maxillofac Surg 1998;56:103-5.

51. Maclntosh RB. Discusión: The "green stick" fracture technique for adaptation and fixation of costochondral grafts. / Oral Maxillofac Surg 1998;56:105.

52. Ellis E, Schneiderman ED, Carlson DS. Growth of the mandible after replacement of the mandibular condyle: An experimental investigation in Macaca mulatta. J Oral Maxillofac Surg 2002;60:1461-70.

53. Bardenheuer E. Citado en: Lexer E. Joint transplantation and arthroplasties. Surg Gynecol Obstet 1925;40:782.

54. Datillo JD, Granick SM, Sotereanos GC. Free vascularized whole joint transplant for reconstruction of the temporomandibular joint: A preliminary case report. J Oral Maxillofac Surg 1986;44:227-9.

55. Özcan M, Akin S, Özbek S, Kahveci R, Savak E, Karacalar A. Temporomandibular joint reconstruction with free microvascular transfer of the metatarsophalangeal joint: A case report. Microsurgery 1998;18:152-5.

56. Landa LE, Gordon C, Dahar N, Sotereanos GC. Evaluation of long-term stability in second metatarsal reconstruction of the temporomandibular joint. J Oral Maxillofac Surg 2003;61:65-71.

57. Vilkki SK, Hukki J, Nietosvaara Y, Hurmerinta K, Suominen E. Microvascular temporomandibular joint and mandibular ramus reconstruction in hemifacial microsomia. / Craniofac Surg 2002;13:809-15.

58. McCormick SU. Reconstruction of the mandibular condyle using transport distraction osteogenesis. J Craniofac Surg 1997;8:48-52; discusion 53.

59. Hikiji H, Takato T, Matsumoto S, Mori Y. Experimental study of reconstruction of the temporomandibular joint using a bone transport technique. J Oral Maxillofac Surg 2000;58:1270-6.

60. Dean A, Alamillos F. Mandibular distraction in temporomandibular joint ankylosis. Plast Reconstr Surg 1999;104:2021-31.

61. Eppley BL. Distraction lengthening of the mandibular costochondral graft: precautionary note. J Craniofac Surg 2000;11:350-3.

62. Matsuura H, Miyamoto H, Ishimaru J, Kurita K, Goss AN. Effect of partial immobilization on reconstruction of ankylosis of the temporomandibular joint with an autogenous costochondral graft: an experimental study in sheep. Br J Oral Maxillofac Surg 2001;39:196-203.

63. Shenaq SM, Klebuc MJ. TMJ reconstruction during vascularized bone graft transfer to the mandible. Microsurgery 1994;15:299-304. 
64. Shenaq SM, Klebuc MJ. The iliac crest microsurgical free flap in mandibular reconstruction. Clin Plast Surg 1994;21:37-44.

65. Shenaq SM. Refinements in mandibular reconstruction. Clin Plast Surg 1992; 19:809-17.

66. Wax MK, Winslow CP, Hansen J, MacKenzie D, Cohen J, Andersen P, Albert T. A retrospective analysis of temporomandibular joint reconstruction with free fibula microvascular flap. Laryngoscope 2000;110:977-81.

67. Iconomou TG, Zucker RM, Phillips JH. Mandibular reconstruction in children using the vascularized fibula. J Reconstr Microsurg 1999;15:8390.

68. Guyot L, Richard O, Layout W, Cheynet F, Bellot-Samson V, Chossegros C, Blanc JL, Gola R. Long-term radiological findings following reconstruction of the condyle with fibular free flaps. / Craniomaxillofac Surg 2004;32:98-102.

69. Norman JE. Glenotemporal osteotomy as a definitive treatment for recurrent dislocation of the jaw. J Craniomaxillofac Surg 1997;25:103.

70. Karabouta I. Increasing the articular eminente by the use of blocks of porous coralline hydroxylapatite for treatment of recurrent TMJ dislocation. J Cranio-Maxillofac Surg 1990;18:107-13.

71. Costas López A, Monje Gil F, Fernández Sanromán J, Goizueta Adame C, Castro Ruiz P. Glenotemporal osteotomy as a definitive treatment for recurrent dislocation of the jaw. J Craniomaxillofac Surg 1996;24:178-83.

72. Fernández-Sanromán J. Surgical treatment of recurrent mandibular dislocation by augmentation of the articular eminence with cranial bone. J Oral Maxillofac Surg 1997;55:333-8.

73. Kummoona R. Surgical reconstruction of the temporomandibular joint for chronic subluxation and dislocation. Int J Oral Maxillofac Surg 2001;30: 344-8.

74. Kent JN, Zoldos J. Comparative study of TMJ reconstruction with costochondral grafts. J Oral Maxillofac Surg 1995;53:127.

75. Henry $\mathrm{CH}$, Wolford LM. Treatment outcomes for temporomandibular joint reconstruction after proplast-teflon implant failure. J Oral MaxiIlofac Surg 1993;51: 352-358; disc.359-60.

76. Saeed NR, McLeod NMH, Hensher R. Temporomandibular joint replacement in rheumatoid induced disease. Br J Oral Maxillofac Surg 2001;39:71-5.

77. Speculand B, Hensher R, Powell D. Total prosthetic replacement of the TMJ: experience with two systems 1988-1997. Br J Oral Maxillofac Surg 2000;38:360-9.

78. Yih WY, Merrill RG. Pathology of alloplastic interpositional implants in the temporomandibular joint. Oral Maxillofac Surg Clin North Am 1989;1:415-26.
79. Van Loon JP, De Bont LGM, Boering G. Evaluation of temporomandibular joint prostheses: review of the literature from 1964 to 1994 and implications for future prostheses designs. / Oral Maxillofac Surg 1995;53:984-96.

80. Mercuri LG, Wolford LM, Sanders B, White D, Giobbie-Hurder A. Longterm follow-up of the CAD/CAM patient fitted total temporomandibular joint reconstruction system. J Oral Maxillofac Surg 2002;60:14408.

81. Wolford LM, Pitta MC, Reiche-Fischel O, Franco PF. TMJ concepts / Techmedica custom-made TMJ total joint prostheses: 5-year followup study. Int J Oral Maxillofac Surg 2003;32:268-74.

82. Saeed NR, Hensher R, McLeod NMH, Kent JN. Reconstruction of the temporomandibular joint autogenous compared with alloplastic. $\mathrm{Br}$ J Oral Maxillofac Surg 2002;40:296-9.

83. Zardeneta G, Mukai H, Marker V, Milam SB. Protein interactions with particulate teflon: Implications for the foreign body response. J Oral Maxillofac Surg 1996;54:873-8.

84. Rae T. The macrophage response to implant materials - with special reference to those used in orthopedics. CRC Crit Rev Biocompat $1986 ; 2: 97$

85. Thornhill TS, Ozuna RM, Shorrtkroff S, Keller K, Sledge CB, Spector M. Biomechanical and histologic evaluation of the synovial-like tissue around fraided (loose) total joint replacement prostheses in human subjects and a canine model. Biomaterials 1990;3511:69-72.

86. Spagnoli D, Kent JN. Multicenter evaluation of temporomandibular joint Proplast-Teflon disk implant. Oral Surg Oral Med Oral Pathol 1992;74:411-21.

87. Wolford LM. Temporomandibular joint devices: treatment factors and outcomes. Oral Surg Oral Med Oral Pathol Oral Radiol Endod 1997;83:143-49.

88. Berarducci JP, Thompson DA, Scheffer RB. Perforation into middle cranial fossa as a sequel to use a Proplast-Teflon implant for TMJ reconstruction. J Oral Maxillofac Surg 1990;48:496-8.

89. McBride KL. Total temporomandibular joint reconstruction. En: Worthington P, Evans JR, eds: Controversies in Oral \& Maxillofacial Surgery. 1994;381-396. WB Saunders. Philadelphia.

90. Feinberg SE, Hollister SJ, Halloran JW, Chu G, Krebsbach PH. Role of biomimetics in reconstruction of the temporomandibular joint. Oral Maxillofac Surg Clin North Am 2000;12:149-60.

91. Glowacki J. Engineered cartilage, bone, joints, and menisci. Potencial for temporomandibular joint reconstruction. Cells Tiss Organs 2001; 169:302-8 